\title{
IMPACTION GRAFTING OF LARGE ACETABULAR DEFECTS
}

\section{REKONSTRUKCIJA VELIKIH ACETABULARNIH DEFEKTOV Z METODO IMPAKTIRANJA KOSTNIH PRESADKOV}

\author{
Boštjan Kocjančič ${ }^{1}$, Lovro Suhodolčan', Klemen Avsec ${ }^{1}$, Matjaž Godec ${ }^{2}$, \\ Barbara Šetina Batič ${ }^{2}$, Črtomir Donik ${ }^{2}$, Monika Jenko², Drago Dolinar ${ }^{1}$ \\ ${ }^{1}$ University Medical Centre Ljubljana, Department of Orthopedic Surgery, Zaloška cesta 9, 1000 Ljubljana, Slovenia, \\ Institute of Metals and Technology, Lepi pot 11, 1000 Ljubljana, Slovenia \\ dolinardrago@gmail.com
}

Prejem rokopisa - received: 2018-03-06; sprejem za objavo - accepted for publication: 2018-05-24

doi: $10.17222 / \mathrm{mit} .2018 .036$

\begin{abstract}
Revision surgery of the hip on the acetabular side is a challenge, especially in the presence of extensive bone loss. Although the impaction allografting of morsellised bone combined with the cement fixation of acetabular implants is still commonly used in revision hip surgery, it fails in most extensive acetabular defects. A series of twelve impaction allograft acetabular revisions is presented. Eleven defects were combined, defined as cavitary and segmental. In one case, there was only medial bone loss, with intact and supportive columns. Of the total number of revised hips, four needed to be re-revised and were considered failures, while two of them suffered repeated dislocations. All failures were observed in the Paprosky type 3B group. Taking aseptic loosening as an end-point, the overall reconstruction survival rate was $66.7 \%$ at an average of 58.4 months. In patients with uncontained segmental acetabular wall defects, we prefer the use of supplemental devices in order to close the peripheral defects combined with a bone-impaction technique. The use of either an acetabular reconstruction ring or trabecular metal acetabular components with augments in combination with impacted bone allografts initially offers a more stable construct, while the impacted allografts are incorporated into the host bone. SEM, EBSD and AES analyses of the retrieved metal meshes and a new one are also presented.
\end{abstract}

Keywords: large acetabular defects, impaction grafting, metal mesh, SEM, EDS, EBSD, AES

Revizija kolčne endoproteze predstavlja kirurški izziv, zlasti ob prisotnosti obsežne izgube kosti na acetabularni strani. Čeprav se metoda impaktiranja kostnih presadkov v kombinaciji s cementiranimi acetabularnimi čašicami še vedno pogosto uporablja pri reviziji kolčne endoproteze, ta odpove pri najbolj obsežnih acetabularnih defektih. Predstavljamo serijo dvanajstih revizij acetabularnih komponent kolčne endoproteze. Enajst acetabularnih defektov je bilo kombiniranih, opredeljenih kot kavitarni in segmentni. V enem primeru je prišlo zgolj do izgube kostnine medialno z nepoškodovanim acetabularnim obodom. Od skupnega števila revidiranih kolkov je bilo štiri potrebno ponovno operativno revidirati in štejejo za neuspešni poskus zdravljenja s to metodo, dva od teh sta imela ponavljajoče izpahe. Vsi neuspešni poskusi zdravljenja spadajo po klasifikaciji v skupino Paprosky tip 3B. Pri aseptično omajanih rekonstrukcijah acetabularnih komponent kolčnih endoprotez je bilo skupno preživetje rekonstrukcij $66,7 \%$ v povprečju 58,4 meseca po operativnem posegu. Pri bolnikih z obsežnimi segmentnimi acetabularnimi defekti dandanes raje uporabljamo druge rekunstruktivne metode. Uporaba bodisi acetabularnih rekonstrukcijskih obročev ali trabekularnih kovinskih acetabularnih komponent $\mathrm{v}$ kombinaciji s kostnimi presadki nudi bolj stabilen konstrukt, s konstantnejšimi in boljšimi kliničnimi rezultati. Predstavljene so tudi SEM-EDS, SEM-EBSD in AES analize dopolnilnih kovinskih pripomočkov, odstranjenih pri revizijski operaciji in novih mrežic iz nerjavnega jekla AISI 316L.

Ključne besede: veliki acetabularni defekti, impaktiranje kostnih presadkov, kovinska mrežica, SEM, EDS, EBSD, AES

\section{INTRODUCTION}

A total hip arthroplasty (THA) ranks as one of the most successful operations yet devised. ${ }^{1}$ As the number of THA increases and the indications for hip replacement widen, the number of failures continues to rise. Projection models predict an increase in demand for revision arthroplasties over the next two decades. The prevalence of revision hip arthroplasty is $18 \%$ in the United States and $8 \%$ in the Swedish registry. ${ }^{2,3}$ Substantial bone loss after THA presents a challenge in reconstruction, as numerous patients have more than one failed revision surgery of serious cavitary and segmental acetabular defects. The indications for acetabular revision include symptomatic aseptic loosening with migration of the component, failure of the fixation, infection, wear, osteolysis, and instability. Progressive osteolysis in an asymptomatic patient and severe wear or bone loss that could compromise a future reconstruction represents relative indications. ${ }^{3}$ Revision surgery of the hip on the acetabular side is a challenge, especially in the presence of extensive bone stock loss. The goals of revision surgery on the acetabular side are to provide an initial support for the cup, the restoration of the anatomic hip center and leg length, to provide conditions for long-term durability, and to restore bone stock for future revisions. ${ }^{4}$

Various reconstruction techniques for extensive acetabular bone defects including large jumbo uncemented acetabular components, bilobed acetabular components, the reconstruction with a high hip centre, a cemented or cementless component revision with impaction grafting, reinforcement rings and cages, and structural bone allografts as well as impaction bone grafting are described by several authors. ${ }^{3,5-14}$ The impaction allografting of morsellised bone combined with the cement fixation of 
acetabular implants is commonly used in revision hip surgery because it offers the opportunity for restoration and regeneration of bone stock. Furthermore, it allows the creation of an anatomic, biomechanical natural center of rotation. ${ }^{15}$ Although initial studies have shown good results, other studies have identified potential problems with this technique. ${ }^{15,16-20}$ Long-term survival rates for massive acetabular deficiencies have been reported between $72 \%$ and $94 \%$. Nevertheless, impaction grafting in most extensive acetabular defects (Paprosky 3A and $\mathrm{B}$, AAOS III) is controversial and always requires the use of supplemental devices such as metal mesh fixed to the iliac bone to transform non-contained into contained deficiencies. ${ }^{12,15,21}$

The paper presents short- to mid-term results for the use of original impaction bone grafting with a metal mesh in order to reconstruct extensive acetabular defects. The results of the failure analyses of the metal mesh, using scanning electron microscopy (SEM), electronbackscattered diffraction (EBSD), Auger electron spectroscopy (AES) and X-ray photoelectron spectroscopy (XPS) methods are also included.

\section{METHODS}

We have reviewed a consecutive series of twelve impaction allograft acetabular revisions and studied the clinical and radiological outcomes to identify the factors associated with the failure of reconstruction. Between February 2010 and November 2012, twelve impaction allograft reconstructions of the acetabulum were performed, of these seven were 2 female and 5 were male patients. The average age of the patients at operation was 68.7 years (range 49.6 to 84.4 ). Pre- and post-operative radiological and clinical data of the twelve hips were available for review. The reason for revision was aseptic loosening in ten hips and septic loosening in two hips. In ten patients $(83.3 \%)$ an isolated acetabular revision was undertaken, and in two $(16.7 \%)$ both components were revised.

Surgeries were performed according to the principles established by Schreurs et al. and Slooff et al. with Exeter X-change revision instrumentation (Stryker Howmedica Osteonics, Allendale, New Jersey) under epidural hypotensive anesthesia and through a posterolateral approach. ${ }^{16,17}$ The acetabulum and femur were widely exposed, obtaining complete visualization of the acetabular limits and its anterior, superior, and posterior segmental defects. All implants, polymethylmethacrylate (PMMA), granulation tissue and interface were removed completely and the transverse ligament or the inferior teardrop was identified. These landmarks allowed the reconstruction of the center of rotation in an anatomic position. The specific requirements for the metal mesh were determined by inserting a trial cup at the transverse ligament level. Pre- and peri-operatively, all the patients were screened for infection using blood tests, bone scans and intra-operative cultures. Cemented polyethylene acetabular components were used. The allograft bone was obtained from our own bone bank, where femoral heads were deep-frozen after harvesting. The donor selection conformed to the guidelines of the Musculosceletal Council of the American Association of Tissue Banks. ${ }^{22}$ Before impaction the allograft bone was thawed at room temperature and prepared by hand with a rongeur and bone mill to produce bone chips of approximately $0.7 \mathrm{~cm}$ to $1 \mathrm{~cm}$ in diameter. All the cartilage was removed first. The acetabular host bone was reamed until a bleeding bone bed was created. If necessary, small drill holes were made for revascularization of the host bone. The bone graft was forcefully impacted until a solid new bone bed was created using Stryker impaction instrumentation (Stryker Howmedica Osteonics). The acetabular components were cemented with Palacos ${ }^{\circledR}$ cement containing gentamicin (Heraeus Medical) using a pressurizing technique recommended by the manufacturer in order to produce a cement mantle at least $2 \mathrm{~mm}$ thick. Metal meshes (Stryker Howmedica Osteonics) were used in all the presented cases. The acetabular metal mesh was $0.38 \mathrm{~mm}$ thick and had $2-\mathrm{mm}$ perforations. The caudal rim of the component was positioned at the level of the transverse ligament. That mesh was trimmed and shaped according to the segmental deficiency. Once placed in position, it was fixed to the iliac bone with several bicortical screws using 15-20 mm interval in between in order to get a stable fixation of the metal mesh. The rehabilitation protocol included early mobilization and ambulation with a walker and toe-touch weight bearing on the operated side for $45 \mathrm{~d}$. After that the patients were encouraged to progressive weight bear as tolerated until they were free of walking assistance (range, 45-110 d).

We evaluated the patients clinically and radiologically. Radiostereometry analysis x-rays were taken at $(15,45,90$ and 180) d postoperatively and then yearly. A clinical assessment was made with a Harris Hip Score. We classified the acetabular bone deficiencies radiographically based on the pre-operative radiograph as well as intraoperative findings using the American Academy of Orthopaedic Surgeons (AAOS) classification and the Paprosky classification.

Eleven defects were combined (Paprosky Type 3, AAOS III), defined as cavitary and segmental. In four cases there were segmental defects with non-supportive columns and superolateral migration (Paprosky type 3A) and in seven cases extensive segmental acetabular defects with superomedial migration were noted (Paprosky type $3 \mathrm{~B}$ ). In one case, there was only medial bone loss, with intact and supportive columns (Paprosky 2C, AAOS II). We excluded cases with pelvic discontinuity, septic failures, cases where the acetabular component was retained, and cases where major structural grafts, augments, or reinforcement cages were utilized. Clinical failure was defined as the need for further acetabular 
revision, regardless of the etiology. Radiographic failure was defined as the progression of radiolucent lines in the three acetabular areas or migration greater than $5 \mathrm{~mm}$.

The samples of retrieved and new metal meshes (stainless steel AISI 316L) were prepared using a Jeol IB-09010CP ion cross-section polisher which produces pristine cross-sections of samples and creates a mirrored surface. The $\mathrm{CP}$ uses an argon beam to mill the crosssections and polish the material.

The microstructures of the samples were investigated using a JEOL JSM 6500F field-emission scanning electron microscope (SEM) equipped with a HKL Nordlys II electron-backscatter diffraction (EBSD) camera using Channel 5 software. Individual diffraction patterns were obtained together with mapping of the area of the interest. The instrument was operated at $15 \mathrm{kV}$ and approximately 2-nA current for the EBSD analysis, with a tilting angle of $70^{\circ}$. The instrument is equipped with EDS technique of Oxford instruments for chemical analysis. The instrument has both secondary-electron (SE) and backscattered-electron (BE) imaging modes for morphological analyses of the samples. For the SE or BE imaging, the instrument was operated with an acceleration of $15 \mathrm{kV}$ at a current of approximately $0.5 \mathrm{nA}$. The vacuum was maintained below $1 \cdot 10^{-6}$ mbar.

The Auger electron spectroscopy (FE-AES) instrument used in this study was a Thermo Scientific Microlab 310-F spectrometer, equipped with a thermally assisted Schottky field-emission electron gun (FEG) that provides a stable electron beam in the accelerating voltage range $0.5-25 \mathrm{kV}$, and a spherical-sector electron kinetic energy analyzer. The spectra were usually acquired with a constant retarding ratio (CRR) of 4 , which provides an energy resolution that is $0.5 \%$ of the pass energy. The parameters used in the AES analysis included a $10-\mathrm{keV}$ primary electron beam at a current of $1 \mathrm{nA}$, an angle of incidence of $0^{\circ}$, and an Auger emission angle of $30^{\circ}$. AES depth profiling was performed by argon-ion sputtering at $3 \mathrm{keV}$ and scanning the ion beam over a $2 \mathrm{~mm} \times 2 \mathrm{~mm}$ area. The sputtering rate was about $0.7 \mathrm{~nm} / \mathrm{min}$. The instrument is also equipped with an $\mathrm{X}$-ray source (Mg, Al dual anode), which in combination with the electron-energy analyzer, allows for an XPS surface chemical analysis to be made in the same instrument. The XPS measurements were performed using non-monochromatic $\mathrm{Al}-K_{\alpha}$ radiation $(1486.6 \mathrm{eV})$ with an anode voltage of $12.5 \mathrm{kV}$ and an emission current of $16 \mathrm{~mA}$. For the XPS depth profiling, a 3-keV Ar-ion beam scanned over a $4 \mathrm{~mm} \times 5 \mathrm{~mm}$ area was used, and this corresponded to a $0.1 \mathrm{~nm} / \mathrm{min}$ sputtering rate.

\section{RESULTS AND DISCUSSION}

The minimal post-operative follow-up period was 40 months and the maximum was 73 months, with a mean average of 58 months. Of the 12 revised hips, four needed to be re-revised and were considered failures, 2 of them suffered repeated dislocations. All failures were observed in the Paprosky type 3B group (4 out of 7). Taking aseptic loosening as an end-point, the overall reconstruction survival rate was $66.7 \%$ at an average of 58 months (40-73 months). An average of 2.3 femoral heads were used per case (range 1-4) to reconstruct the acetabular defects. The average time of revision procedure was $225.8 \mathrm{~min}(170-360 \mathrm{~min})$, and the average blood loss was $1467 \mathrm{~mL}(600-2500 \mathrm{~mL})$. A successful clinical result at the last follow up (HHS over 70, stable implant) was observed in eight patients, where the average HHS for all patients at 24 months was 75.6, and in the successful group at last follow up the average HHS was 78.6. The average fleion of the operated hip at the last follow up was $84.2^{\circ}$ (Table 1). During the last examination six out of eight successfully treated patients walked without any aid, while two were using crutches.

Table 1: Details of epidemiology and results

\begin{tabular}{|c|c|c|c|c|c|c|c|c|c|}
\hline No & $\begin{array}{c}\text { Age } \\
\text { (years) }\end{array}$ & Diagnosis & AAOS & Paprosky & $\begin{array}{c}\text { Followup } \\
\text { (mts) }\end{array}$ & $\begin{array}{c}\text { HHS } \\
(24 \text { months })\end{array}$ & $\begin{array}{c}\text { HHS } \\
\text { (at followup) }\end{array}$ & $\begin{array}{l}\text { Revision } \\
\text { (months) }\end{array}$ & observations \\
\hline 1 & 74,8 & $\mathrm{AL}$ & IB & $2 \mathrm{C}$ & 67 & 79 & 79 & & \\
\hline 2 & 84,4 & $\mathrm{AL}$ & III & $3 \mathrm{~B}$ & 41 & 69 & 69 & 27 & $\begin{array}{l}\text { repetitive luxations, mesh } \\
\text { failure, reoperation }\end{array}$ \\
\hline 3 & 69,8 & $\mathrm{AL}$ & III & $3 \mathrm{~B}$ & 40 & 82 & 84 & & \\
\hline 4 & 68,1 & $\mathrm{AL}$ & III & $3 \mathrm{~A}$ & 64 & 84 & 85 & & \\
\hline 5 & 49,6 & $\mathrm{AL}$ & III & 3B & 73 & 73 & 71 & 47 & $\begin{array}{l}\text { breakage of reconstruction, } \\
\text { reoperation }\end{array}$ \\
\hline 6 & 82,4 & $\mathrm{AL}$ & III & $3 \mathrm{~B}$ & 52 & 82 & 76 & & \\
\hline 7 & 72,8 & $\mathrm{AL}$ & III & $3 \mathrm{~A}$ & 52 & 75 & 79 & & \\
\hline 8 & 54,7 & $\mathrm{AL}$ & III & $3 \mathrm{~B}$ & 68 & 79 & 78 & & \\
\hline 9 & 73,3 & SL & III & $3 \mathrm{~B}$ & 64 & 59 & 58 & 39 & $\begin{array}{l}\text { infection, debridement, } \\
\text { retention }\end{array}$ \\
\hline 10 & 57,5 & AL & III & $3 \mathrm{~B}$ & 48 & 69 & 67 & 32 & $\begin{array}{l}\text { repetitive luxations, } \\
\text { reoperation }\end{array}$ \\
\hline 11 & 64,8 & $\mathrm{AL}$ & III & $3 \mathrm{~A}$ & 57 & 81 & 83 & & \\
\hline 12 & 72,3 & SL & III & $3 \mathrm{~A}$ & 70 & 77 & 76 & & \\
\hline
\end{tabular}

AL, aseptic loosening; SL, septic loosening; HHS, AAOS, Academy of Orthopedic Surgeons 

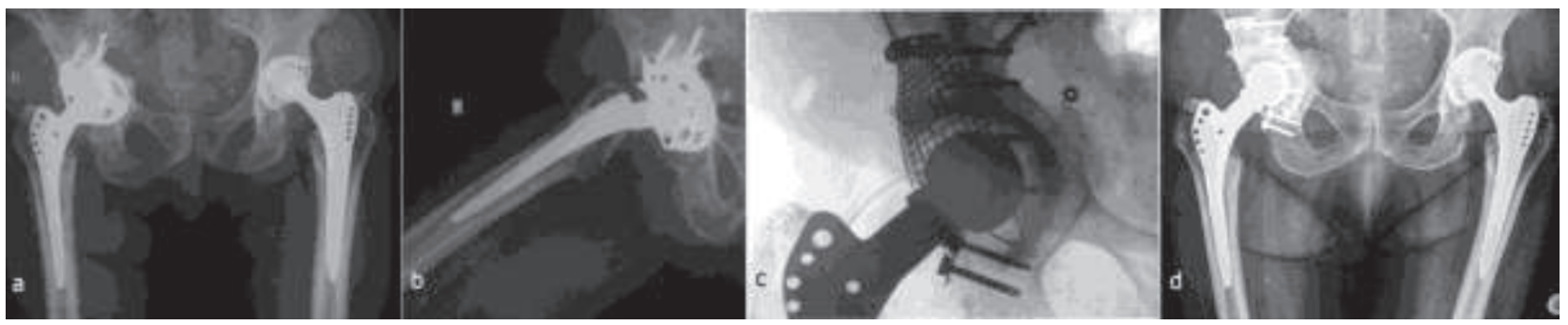

Figure 1: X-ray images of a successful reconstruction with the impaction allografting technique

One patient had an acute deep haematogenous infection of the revised hip after an infection of the urinary tract without radiographic signs of loosening or migration $39 \mathrm{~m}$ postoperatively. The patient was treated with surgical debridement, component retention, and antibiotic therapy suppression, and showed no signs of loosening $64 \mathrm{~m}$ after the initial reconstruction. Two of the patients presented with a positive post-operative Trendelenburg test. One patient also had a transient palsy of the sciatic nerve; no other major problems were noted. The length of the leg was restored completely in 10 patients. In two patients who had a pre-operative shortening of $5 \mathrm{~cm}$, the remaining shortening was $1 \mathrm{~cm}$.

In the following section one typical case of a successful reconstruction and two examples of failed reconstructions with impaction allografting will be presented.

Case 1: A preoperative radiograph of a patient showing a loose Muller reinforcement ring of the right hip (Figures 1a, 1b). Moderate segmental and cavitary acetabular deficiency (AAOS type III, Paprosky type 3A) was successfully reconstructed with impaction allografting (Figures 1c, 1d). Figure 1c shows an immediate post-op radiograph, Figure 1d shows a stable situation of the reconstruction at latest follow-up $(70 \mathrm{~m}$ postop).

Case 2: A patient that suffered failure of Paprosky 3B acetabular reconstruction (extensive posterior and moderate medial wall deficiency) $39 \mathrm{~m}$ after impaction grafting. Figure 2a shows a good and successful reconstruction with the Exeter method at follow-up. Later on, the breakage of the reconstruction was caused by hip dislocation, which occurred during the spinal decompression surgery (Figure 2b). A bent mesh and pulled screws of the posterior acetabulum reconstruction were noted. Massive segmental deficiency was re-reconstructed with a Burch-Schneider reinforcement cage (Zimmer) (Figure 3c).

Case 3: A patient who had multiple reconstructions of combined extensive segmental and cavitary deficiency of the right acetabulum (Paprosky 3B, AAOS III). After complete breakage of Burch-Schneider Reinforcement Cage (Zimmer)(Figures 3a, 3b), impaction allografting

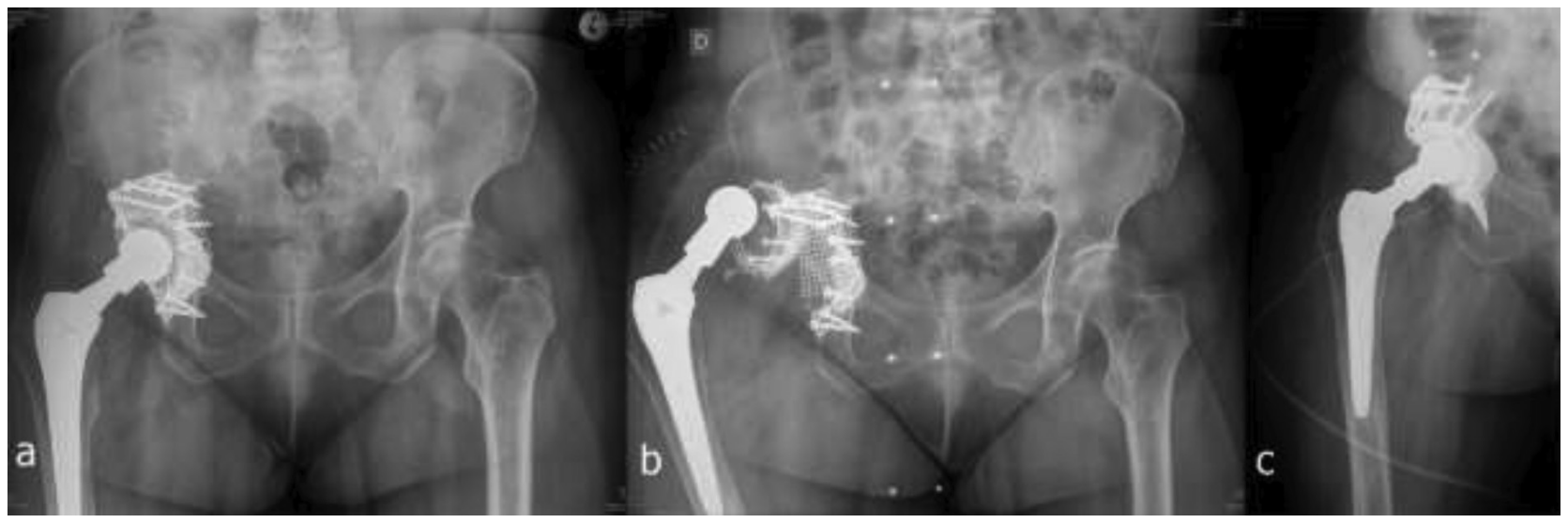

Figure 2: X-ray images of an unsuccessful reconstruction with metal mesh and impaction bone grafting in a segmental acetabular defect

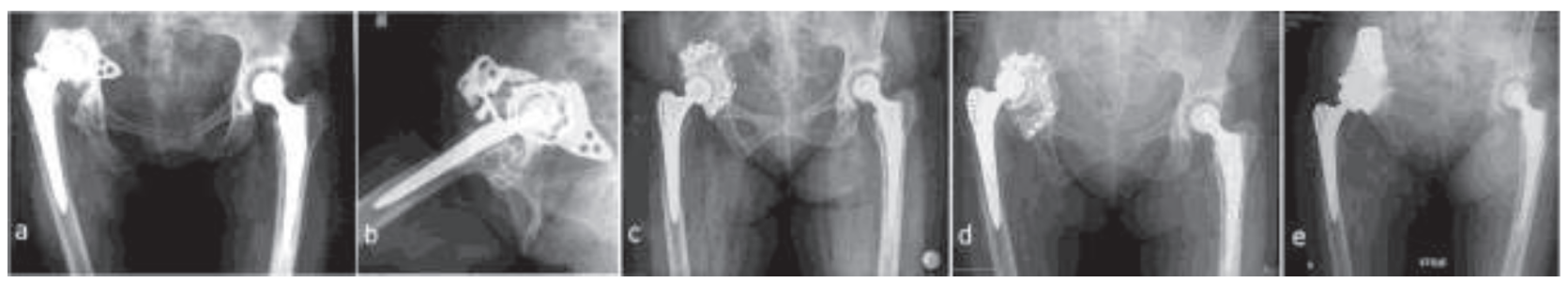

Figure 3: X-ray images of a failed re-revision with the Exeter technique. Mesh breakage after 27 months. Further re-reconstructed with Trabecular Metal ${ }^{\mathrm{TM}}$ Acetabular Revision System (Zimmer). 
using the Exeter technique was employed (Figure 3c). The mesh reconstruction failed after $27 \mathrm{~m}$ (Figure 3d) and was further re-reconstructed with Trabecular Metal ${ }^{\mathrm{TM}}$ Acetabular Revision System (Zimmer) (Figure 3e).

\subsection{SEM, EDS and EBSD}

The microstructures of the retrieved and new metal meshes are shown in Figure 4. Channelling contrast from differently oriented grains can be seen from the backscattered-electron image, with twin grains present, as well as some inclusions. The EDS analysis (Table 2), performed over a larger area, corresponds well to the composition of the AISI $316 \mathrm{~L}$ stainless steel, as can be seen from Table 2. The inclusions present are mostly oxides. No porosity was observed in the images.

Table 2: EDS analyses of fractured metal mesh and new metal mesh $(w / \%)$

\begin{tabular}{|l|c|c|c|c|c|c|}
\hline \multicolumn{1}{|c|}{ Element } & $\mathrm{Si}$ & $\mathrm{Cr}$ & $\mathrm{Mn}$ & $\mathrm{Fe}$ & $\mathrm{Ni}$ & $\mathrm{Mo}$ \\
\hline Fractured metalmesh & 0.5 & 17.8 & 2.4 & 61.7 & 14.6 & 3.0 \\
\hline New metal mesh & 0.5 & 17.9 & 2 & 61.6 & 14.4 & 3.5 \\
\hline
\end{tabular}

An additional EBSD analysis was performed to characterise the crystal structure and grains of the new and the retrieved mesh. The analysis showed an austenitic (fcc) crystal structure, with no prevalent texture. The
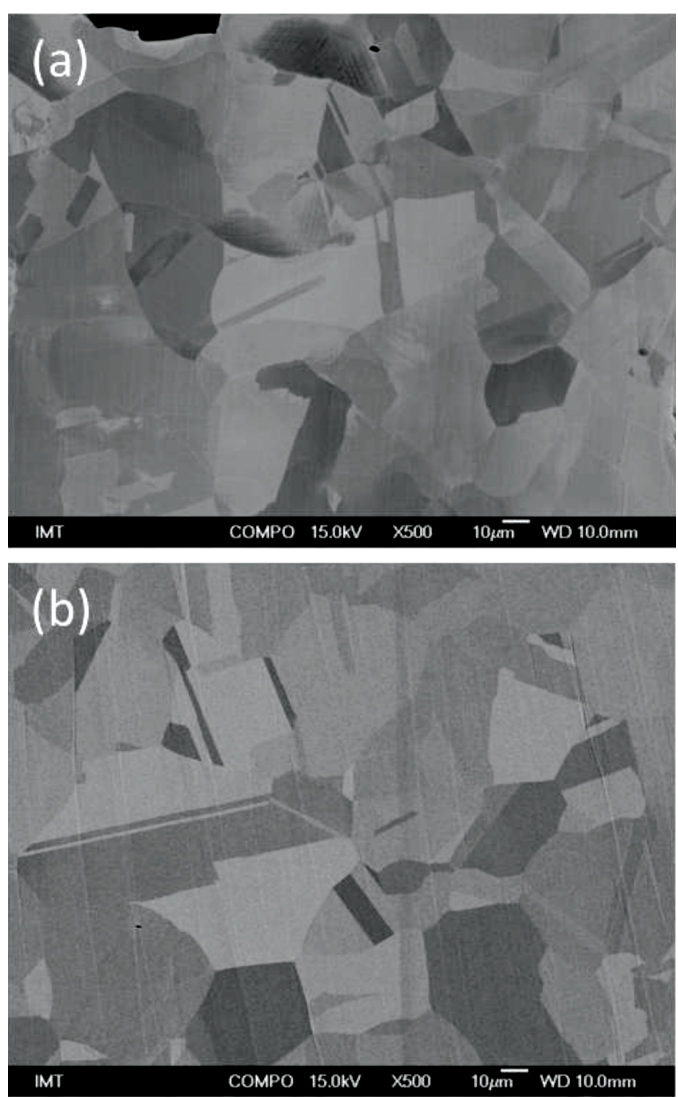

Figure 4: a) BE image of cross-section microstructures of retrieved and b) new metal mesh
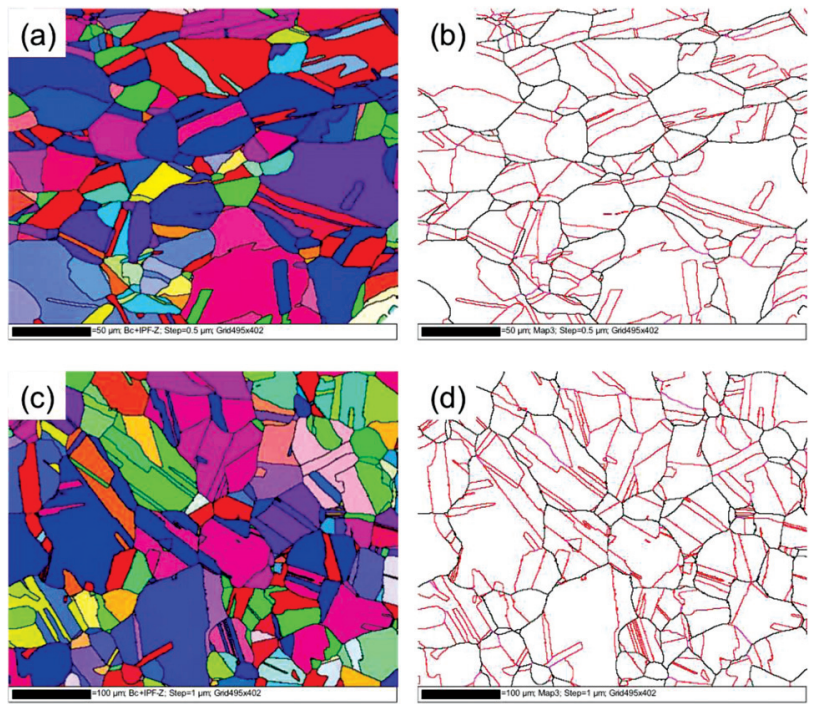

Figure 5: EBSD analysis of the metal mesh: a) orientation map of the new mesh, b) grain reconstruction of the new mesh, CSL $\Sigma 3$ grain boundaries are shown in red, c) orientation map of the retrieved mesh, d) grain reconstruction of the new mesh, CSL $\Sigma 3$ grain boundaries are shown in red

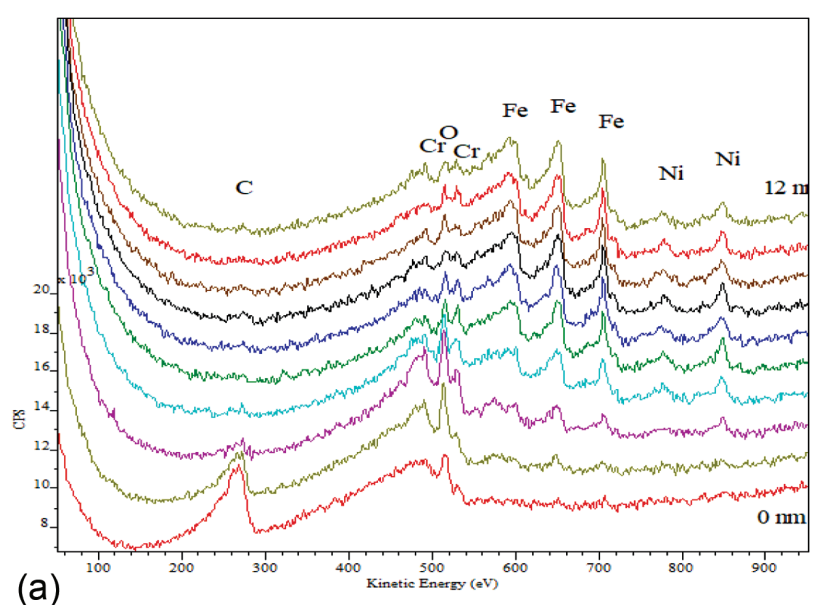

(a)

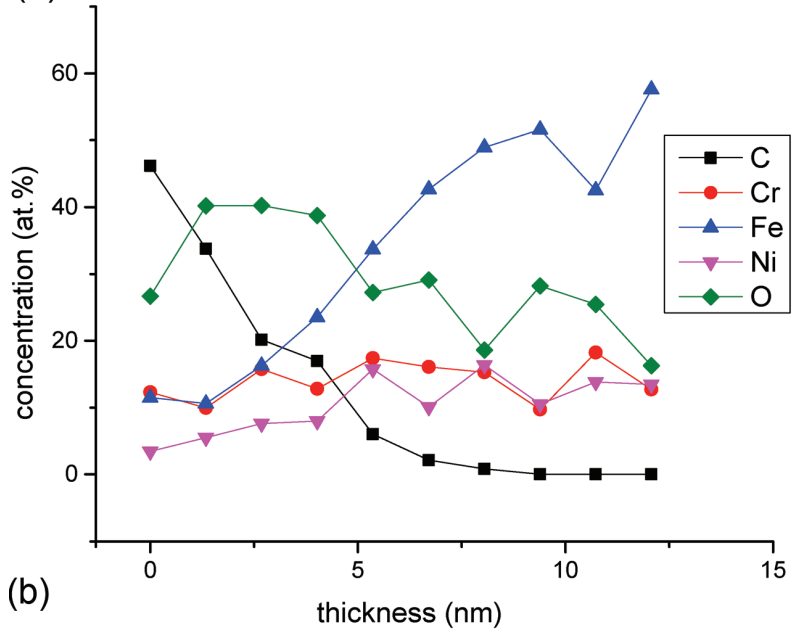

Figure 6: a) AES spectra, taken on retrieved metal mesh (AISI 316L), b) AES depth profile of the same metal mesh 


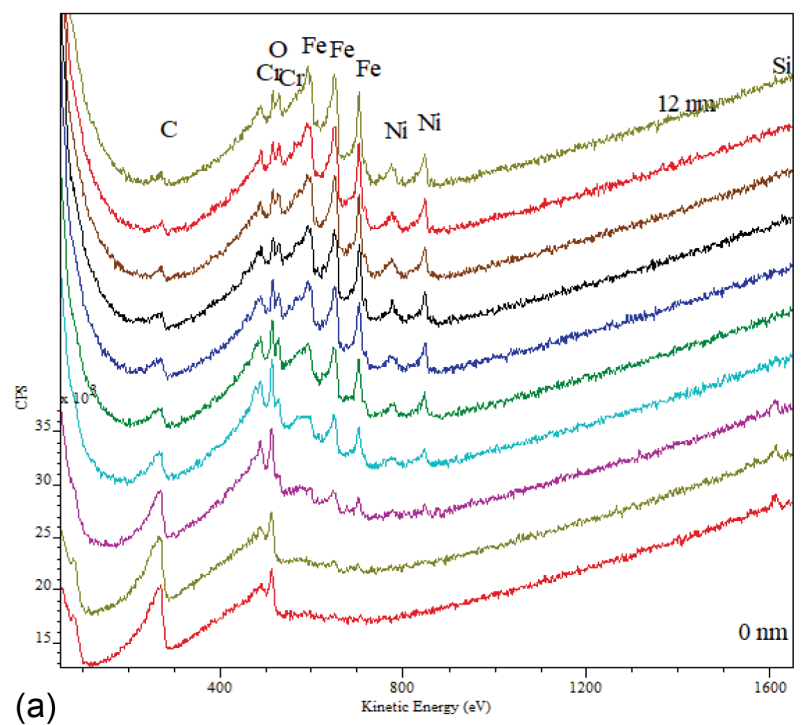

(a)

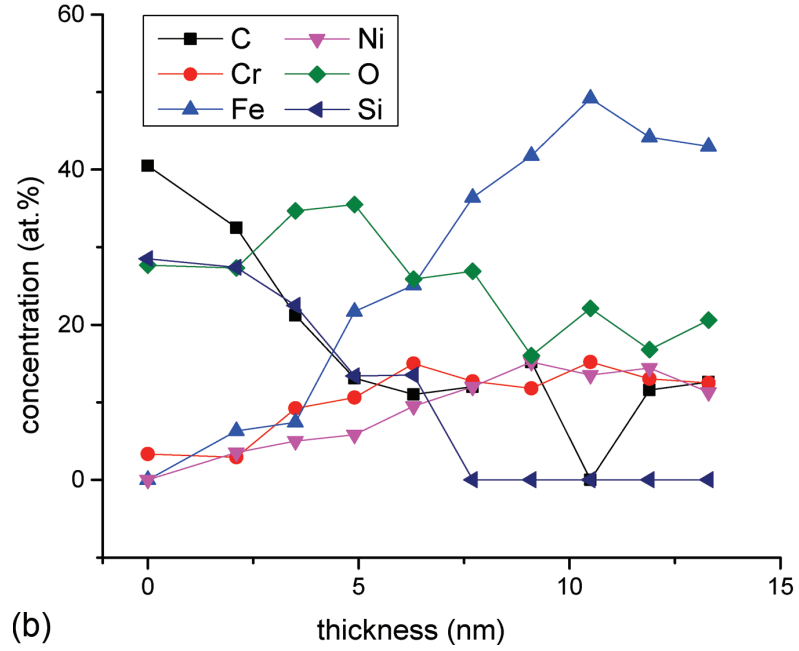

Figure 7: a) AES spectra, taken on new metal mesh (AISI 316L), b) AES depth profile of the same metal mesh

images in Figures $\mathbf{5 a}$ and $\mathbf{5 c}$ show the orientation mapping of the new and retrieved mesh, while $\mathbf{5 b}$ and $\mathbf{5 d}$ show the grain reconstruction, with $\Sigma 3$ grain boundaries shown in red color. The retrieved mesh shows a slightly higher percentage of twin boundaries, with $65 \%$ of the total grain-boundary length corresponding to twins; while the new mesh has about $60 \%$ of twin boundaries. The twinning in the austenitic stainless steel is due to fatigue and plastic deformation. The grain sizes are similar in both cases.

\subsection{AES and XPS}

AES and XPS surface analysis confirm the presence of a thin, passive $\mathrm{Cr}_{2} \mathrm{O}_{3}$ film contaminated by carbon.

The thin oxide films on the surfaces of the fractured AISI $316 \mathrm{~L}$ austenitic stainless-steel mesh retrieved and new were analyzed by AES. Figures $\mathbf{6 b}$ and $\mathbf{7 b}$ show the AES depth profiles of a thin oxide film on the AISI 316 L stainless steel of the retrieved and new metal meshes.

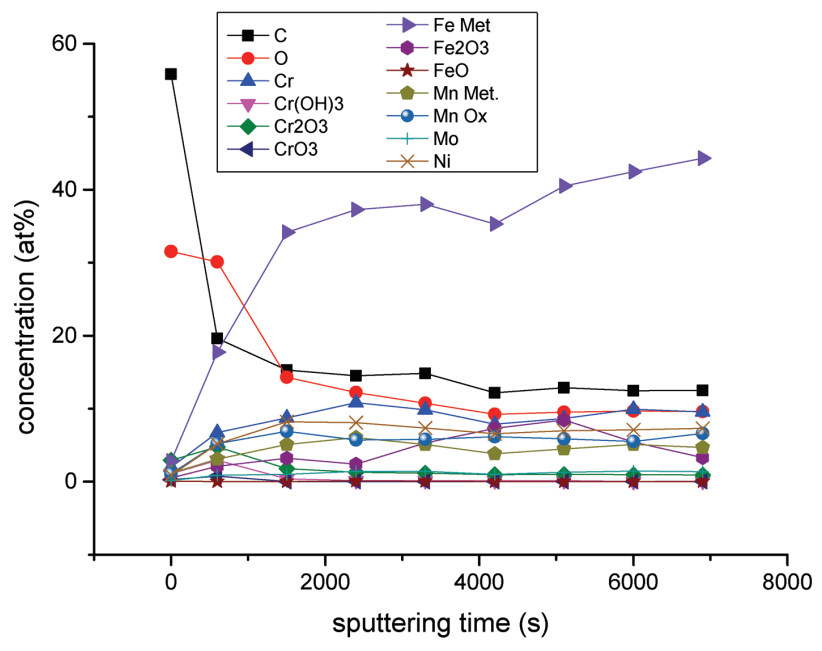

Figure 8: XPS depth profile of retrieved metal mesh (27 month)

Figure 8 represents the XPS depth profile of the mesh after $27 \mathrm{~m}$ use in patients with all possible species on the stainless-steel surface. The film on the surface shows a very thin oxide layer with predominantly $\mathrm{C}, \mathrm{O}$ and from the kationic fraction $\mathrm{Cr}$ as $\mathrm{Cr}_{2} \mathrm{O}_{3}$. The present cationic fractions shown in Figure 8 are also $\mathrm{Fe}$ and $\mathrm{Cr}$ in metallic form, but this is not due to the non-uniform passive film, but the thickness is so small that we can observe the matrix below the oxide layer.

Since AES and XPS are surface-sensitive techniques we can measure the thicknesses of the thin oxide films. We calculated on both the retrieved and new metal meshes an about 2-nm-thick oxide film.

\section{CONCLUSIONS}

The management of Type $3 \mathrm{~A}$ or $3 \mathrm{~B}$ defects of the acetabulum according to Paprosky is one of the most challenging aspects of revision hip arthroplasty. Due to the fact that many of these patients have a long life expectancy it is of fundamental importance to re-establish the bone sub layer of the acetabulum and also to reestablish the rotation center of the hip as much as possible back to its anatomic place. Different operative methods can be used to achieve this goal, but none has a good long-term survival of the implant.

Although managing this kind of revision hip surgery using the impaction allografting of morsellised bone combined with metal meshes and cemented fixation showed promising survival rates at the beginning, longer follow up studies have identified potential problems, especially when treating extensive segmental acetabular defects. ${ }^{15-20}$

Our series found an unacceptably high rate of failure of impaction grafting for acetabular revision. The majority of patients (11 of 12) analyzed in our study had large, combined, uncontained defects of acetabulum with non-supportive columns. In our series a $57 \%$ failure rate was noted in the subgroup with large, uncontained, seg- 
mental defects with major medial bone loss (Paprosky 3B), and none in the moderate combined acetabular bone loss (Paprosky 3A type group). Our study confirmed good-to-excellent survival rates and clinical results when using the impaction allografting of morsellised bone with metal meshes in Paprosky type 2C and type 3A segmental defects of the acetabular wall. Furthermore, when using this technique in the uncontained extensive segmental acetabular wall defects (Paprosky type 3B), the survival rates of the construct fall significantly.

Our findings are similar to the study of van Haarens and Buttaros, as we consider extreme segmental defects combined with major medial wall defects (Paprosky type 3B) a contra-indication for the use of metal mesh with impaction bone grafting. A possible explanation for the relatively high failure rates may include micro movement leading to mechanical instability and graft resorption followed by stainless-steel fatigue resulting in mesh rupture and migration. ${ }^{12,15}$ Another important factor is the quality of the host bone that is usually significantly more affected in extreme acetabular defects. Good bone quality is of major importance for adequate graft incorporation, which is essential for the survival of the construct. ${ }^{12}$

Furthermore, our explanation for the observed instability and repeated dislocation in two of our patients would be that thick bone grafting allows for greater subsidence of cemented acetabulum. Additionally, it is sometimes advisable to make more soft-tissue tension in these types of revision procedures in order to achieve better stability of the implant that can lead to excessive leg lengthening and puts adjacent neurovascular structures at risk.

The latter is especially the case with the sciatic nerve, since the operative management of great posterior acetabular wall defects requires its relatively large exposure in order to properly fix the metal mesh. Extensive exposure often means close contact with the sciatic fossa and visualization of the nerve. Taking this into consideration, we believe that only one transient palsy was a very successful result in our clinical setting.

Recently, in patients with uncontained segmental acetabular wall defects we prefer to use supplemental devices to close the peripheral defects combined with the bone-impaction technique.

The use of either an acetabular reconstruction ring or trabecular metal acetabular components with augments in combination with impacted-bone allografts initially offers a more stable construct, while the impacted allografts are incorporated into the host bone. ${ }^{23}$

We believe that a metal mesh fixed to the ilium combined with impacted allografts and a cemented cup has its primary role in the contained cavitary and moderatesize uncontained cavitary acetabular defects (AAOS type I and II, Paprosky type 2 and 3A), where high survival rates were reported. ${ }^{15-18}$ On the other hand, we found worryingly high failure rates with this reconstruction technique in cases with large segmental defects, which concurs with authors who have identified the same potential problem. ${ }^{15,19}$

The limitations of our study include a small patient cohort, but taking into account also the published data in the literature we can conclude that in the selected revision cases with moderate acetabular wall defects the impaction grafting technique combined with metal meshes is good and provides a biological restoration of the bone stock. In revisions with extensive acetabular bone defect the same technique carries with it a high risk of failure. ${ }^{15-20}$

SEM and EBSD analyses showed an austenitic microstructure with numerous twin grains due to fatigue and plastic deformation. AES and XPS surface analyses of the retrieved and new metal mesh confirm the presence of a thin passive $\mathrm{Cr}_{2} \mathrm{O}_{3}$ film contaminated by $\mathrm{C}$ with an estimated thickness of $2 \mathrm{~nm}^{24}$

\section{Acknowledgments}

This work was carried out within the framework of Department of Orthopaedic Surgery University Medical Centre Ljubljana, with no extra funding. The failure analysis of the meshes were carried out at the Institute of Metals and Technology, financially supported by Slovenian Research Agency ARRS-0206-0132.

\section{Ethics statement}

The article does not contain any studies with human participants or animals performed by any of the authors. Informed consent was obtained from all the individual participants included in the study.

\section{Conflict of interest}

The authors declare that they have no conflict of interest.

\section{REFERENCES}

${ }^{1}$ I. D. Learmonth, C. Young, C. Rorabeck, The operation of the century: total hip replacement. Lancet. 27, 370-9597 (2007) 1508-19

${ }^{2}$ S. M. Kurtz, K. L. Ong, Schmier, F. Mowat, K. Saleh, E. Dybvik, J. Kärrholm, G. Garellick, L. I. Havelin, O. Furnes, H. Malchau, E. Lau, Future clinical and economic impact of revision total hip and knee arthroplasty. J Bone Joint Surg Am. 89, 3 (2007), 144-51

${ }^{3}$ S. M. Sporer, W. G. Paprosky, M. R. O'Rourke, Managing bone loss in acetabular revision. Instr Course Lect. 55 (2006), 287-97

${ }^{4}$ D. Garbuz, E. Morsi, N. Mohamed, A.E. Gross, Classification and reconstruction in revision arthroplasty with bone stock deficiency. Clin Orthop Relat Res. 324 (1996), 98-107

${ }^{5}$ C. Wedemeyer, C. Neuerburg, H. Heep, F. von Knoch, M. von Knoch, F. Löer, G. Saxler, Jumbo cups for revision of acetabular defects after total hip arthroplasty: a retrospective review of a case series. Arch Trauma Surg., 128 (2008), 545-50

${ }^{6}$ W. M. Chen, C. A. Engh Jr, R. H. Hopper Jr, J. P. McAuley, C. A. Engh, Acetabular revision with use of a component inserted without cement in patients who have acetabular bone-stock deficiency. J Bone Joint Surg Am. 82, 2 (2000), 197-206 


\section{B. KOCJANČIČ et al.: IMPACTION GRAFTING OF LARGE ACETABULAR DEFECTS}

${ }^{7}$ K. J. Hendricks, W. H. Harris, High placement of noncemented acetabular components in revision total arthroplasty. A concise follow-up, at a minimum of fifteen years, of a previous report. J Bone Joint Surg Am. 88,10 (2006), 2231-6

${ }^{8}$ F. Comba, M. Buttaro, R. Pusso, F. Piccaluga, Acetabular reconstruction with impacted bone allografts and cemented acetabular components: a 2- to 13-year follow-up study of 142 aseptic revisions. J Bone Joint Surg Br. 88, 7 (2006), 865-9

${ }^{9}$ D. Lakstein, D. Backstein, O. Safir, Y. Kosashvili, A. E. Gross, Trabecular Metal cups for acetabular defects with $50 \%$ or less host bone contact, Clin Orthop Relat Res. 467, 9 (2009), 2318-24, doi:10.1007/s11999-009-0772-3

${ }^{10}$ S. H. Weeden, W. G. Paprosky, Porous-ingrowth revision acetabular implants secured with peripheral screws. A minimum twelve-year follow-up. J Bone Joint Surg Am. 88, 6 (2006) 1266-71

${ }^{11}$ A. E. Gross, S. Goodman, The current role of structural grafts and cages in revision arthroplasty of the hip. Clin Orthop Relat Res., 429 (2004), 193-200

${ }^{12}$ M. A. Buttaro, F. Comba, R. Pusso, F. Piccaluga, Acetabular revision with metal mesh, impaction bone grafting, and a cemented cup., Clin Orthop Relat Res. 466, 10 (2008), 2482-90, doi:10.1007/s11999008-0442-x.

${ }^{13}$ S. Goodman, H. Saastamoinen, N. Shasha, A. Gross, Complications of ilioischial reconstruction rings in revision total hip arthroplasty. J Arthroplasty 19, 4 (2004), 436-46

${ }^{14}$ D. Regis, B. Magnan, A. Sandri, P. Bartolozzi, Long-term results of anti-protrusion cage and massive allografts for the management of periprosthetic acetabular bone loss. J Arthroplasty, 236 (2008), 826-32, doi:10.1016/j.arth.2007.06.017

${ }^{15}$ E. H. van Haaren, I. C. Heyligers , F. G. Alexander, P. I. Wuisman, High rate of failure of impaction grafting in large acetabular defects, J Bone Joint Surg, Br. 89, 3 (2007), 296-300
${ }^{16}$ B. W. Schreurs, T. J. Slooff, J. W. Gardeniers, P. Buma, Acetabular reconstruction with bone impaction grafting and a cemented cup: 20 years' experience, Clin Orthop Relat Res., 393 (2001), 02-15

${ }^{17}$ T. J. Slooff, P. Buma, B. W. Schreurs et al., Acetabular and femoral reconstruction with impacted graft and cement, Clin Orthop, 324 (1996), 108-15

${ }^{18}$ M. L. Welten, B. W. Schreurs, P. Buma, N. Verdonschot, T. J. Slooff, Acetabular reconstruction with impacted morcellized cancellous bone autograft and cemented primary total hip arthroplasty: a 10- to 17-year follow-up study, J Arthroplasty, 15 (2000) 819-24

${ }^{19}$ E. Ornstein, I. Atroshi, H. Franzen et al., Early complications after one hundred and fortyfour consecutive hip revisions with impacted morselized allograft bone and cement, J Bone Joint Surg [Am], 84 A (2002), 1323-8

${ }^{20}$ S. A. Lie, L. I. Havelin, O. N. Furnes, L. B. Engesaeter, S. E. Vollset, Failure rates for 4762 revision total hip arthroplasties in the Norwegian Arthroplasty Register, J Bone Joint Surg [Br] 86-B, (2004), 504-9

${ }^{21}$ N. van Egmond, D. C. De Kam, J. W. Gardeniers, B. W. Schreurs, Revisions of extensive acetabular defects with impaction grafting and a cement cup, Clin Orthop Relat Res. 469, 2 (2011), 562-73, doi:10.1007/s11999-010-1618-8

${ }^{22}$ American Association of Tissue Banks: Standards for Tissue Banking - 12th edn. McLean: American Association of Tissue Banks, 2008

${ }^{23}$ A. Nehme, D. G. Lewallen, A. D. Hanssen, Modular porous metal augments for treatment of severe acetabular bone loss during revision hip arthroplasty, Clin Orthop Relat Res., 429 (2004), 201-208

${ }^{24}$ M. Jenko, M. Gorenšek, M. Godec, M. Hodnik, B. Šetina Batič, Č. Donik, J. T. Grant, D. Dolinar, Surface chemistry and microstructure of metallic biomaterials for hip and knee endoprostheses, Applied Surface Science, 427 (2017), 584-593, doi:10.1016/j.apsusc.2017. 08.007 